\title{
Sociopreneurship Business Incubator Design Based On Information Technology as an Innovative Solution for Enhancing Community Welfare
}

\author{
Vieqi Rakhma Wulan ${ }^{1}$, Agus Hermanto ${ }^{2}$ \\ ${ }^{1}$ Department of Management in Faculty of Economics, \\ University of PGRI Adi Buana Surabaya, Indonesia \\ ${ }^{2}$ Department of Engineering in Faculty of Informatics Engineering, \\ University of August $17^{\text {th }} 1945$ Surabaya, Indonesia \\ v.qei@unipasby.ac.id
}

\begin{abstract}
This research aimed is to design a sociopreneurship (Social Entrepreneurship) business incubator system by integrating the Information Technology Infrastructure Library (ITIL) features as a supporting tool in managing business incubator. With the sociopreneurship business incubator design is expected to help overcome social problems that occur in the community. This research is a qualitative research using the Human Centered Design (HCD) method. The stages in this HCD method are Hear, Create and Delivery. However, because the purpose of this study is to design, the stages that are passed are up to the Create stage. Based on the research, business incubators design were produced with 7 business fields, 5 service fields, 2 phases, namely co worker space and event space with details: 5 programs and activities in the co worker space phase and 2 programs and activities in the event space phase. Business incubator system also designed by integrating the Information Technology Infrastructure Library (ITIL) features as a supporting tool in managing business incubator. This research is limited to the design so that the 3 stages of the HCD method are used only up to the second stage, namely the Create stage. In this research, it seeks to accommodate the community's needs for a business field so that services and programs of business incubator can be obtained that are in accordance with the needs of the community. This study also seeks to present a business incubator that is tailored to the needs of the community so that the community does not only have economic independence but can be mutually transmitted and sustainable with other communities (sociopreneurship) and by utilizing information technology. In this study the researchers collected, identified and interpreted the data that had been obtained. For this purpose, a literature review and approach to the HCD method are used through interview techniques by approaching the community and analyzing their needs in order to produce an analysis of results accordingly.
\end{abstract}

Keywords: Business Incubator, Sociopreneurship, ITIL, HCD

\section{INTRODUCTION}

Today, many business incubators are established. Many institutions have established this business incubator. In fact, many universities have also formed business incubators as preparations for students to face the world of business when they finish their studies. Aside from being an alternative to innovation in

Sociopreneurship Business Incubator Design Based On Information Technology As an Innovative Solution for Enhancing Community Welfare

Vieqi Rakhma Wulan, Agus Hermanto 
economic growth and development, business incubators are also used as alternative solutions to overcome existing social problems, such as unemployment and poverty. According to infodev.org (2010) business incubator is a facility or physical space that accommodates a development process that is designed so that economic and social, entrepreneurial, public and/or personal can foster business from an idea that is realized into a new company through comprehensive business support program. So that it can help them build and accelerate their growth and success.

Whereas social problems that occur not only require an entrepreneur but also a social entrepreneur (abbreviated as sociopreneur) who can spawn more entrepreneurs and together to develop and advancing the economy. This is because social entrepreneurship (abbreviated as sociopreneurship) does not only focus on the ability to generate profits but also the ability to empower the community so that it has independence to create welfare equality (Anoviar 2013). So, what is meant by a sociopreneur? Santosa (2007) suggests sociopreneur is someone who understands social problems and uses entrepreneurial skills to make social change, especially in the fields of welfare, education and healthcare. If entrepreneurs who are business-oriented are measuring the success of their financial performance (profit or income), the success of social entrepreneurs is measured by the benefits felt by society.

Business incubators are identical to printing entrepreneurs. The incubation participants (tenants) are given learning facilities, guidance, and other facilities so that they are more prepared and established in the field of sociopreneurship. But the business incubators that are currently developing are still many that lead to business entrepreneurs. There is only one institution in Indonesia that is a special social enterprise business incubator (the culprit is sociopreneur). The institution is Unltd Indonesia (www.unltdindonesia.org). Every year Unltd Indonesia opens the opportunity for novice sociopreneur to become a participant in their incubation program which consists of training, mentoring, network expansion through various sharing sessions that are routinely held, facilitation of grant funds, soft loans, and investment.

The lack of a business incubator that is specialized in sociopreneurship programs makes this institution potentially considerable to develop. Therefore the purpose of this study is to provide an innovation in designing a Business Incubator in the direction of sociopreneurship with information technology support in the form of Information Technology Infrastructure Library (ITIL) to help manage the incubator. The expectation of this research is can contribute to helping address existing social problems.

\section{The History of Business Incubators}

The business Incubator was first introduced in New York (Idris 2012). A building that was previously used to incubate chickens was changed to use to incubate a start up firm. The USA National Business Incubation Association defines business incubator is a tool of economic development that designed to accelerate the growth and success of entrepreneurial companies through a range of business support resources and services. The main purpose of business incubators is produce companies to successful that will leave this program financially feasible and free standing.

\section{The Activities and Services of Business Incubation Program}

According to Harley in Idris (2012) Business Incubators can be interpreted as an organization that regulates the processes to help grow and develop new companies proposed by participants/tenants by providing various kinds of comprehensive and integrated services, namely:

1. Incubator space, can be in the form of office, manufacturing, laboratory, or sales that are available in a flexible, affordable and temporary manner

2. Common Space, facilities provided to tenants such as meeting rooms, reception lobbies and canteens

3. Common Services, such as secretarial support and use of office equipment together

4. Hands-on Counseling, intense counseling assistance and access to special assistance

Sociopreneurship Business Incubator Design Based On Information Technology As an Innovative Solution for Enhancing Community Welfare

Vieqi Rakhma Wulan, Agus Hermanto 
5. Assistance in finding and obtaining business financing or even providing some level of financing for clients

DTBi (2015) mention the stages of incubation consist of:

1. Pre-Incubation, done approximately 3-6 months,

Everyone with an idea is invited to be part of the pre-incubation stage as long as they fulfill one main criterion: the idea solves the problem in the community. If accepted, a bankable idea is created and passed the startup stage. The stages are:

a. Filtering and refining of ideas

b. Guided mentoring and coaching to create bankable of ideas

c. Technical assistance in developing prototype concepts

d. The evaluation of progressive for graduation to the next stage

e. Access to the internet at high speed

f. Events of networking and workshops

g. Helping in market analysis

h. Business capacity development

2. Start up, done approximately 6-12 months,

This incubation stage is for entrepreneurs who has been through and declared passed from pre-incubation stage or for Innovators with prototypes for testing and commercialization. They can be residential or non-residential. During this stage, completion and testing is carried out on the prototype. Innovators are assisted to identify trial locations, develop revenue models and provide various business development support services to support business formalization and monetarization. Startups to pass to the next stage must have at least one client / customer. The steps are as follows:

a. Capacity development and business planning support, management like of company, setup of board, HR, accounts, taxation, and others.

b. Company establishment

c. Support for pilot concept testing

d. Mentoring and coaching

e. Income models development and financial projections

f. Relation to potential markets

g. Exposure to expert speakers, training and marketing events

h. The evaluation of progressive for graduation to the next stage

i. Access to initial capital (financial/grants) if possible

j. Space in a safe building

k. Access to the internet at high speed

1. Events of networking

m. Displays, workshops, and hackerthons

3. Company Incubatess, done up to 4 years,

Sociopreneurship Business Incubator Design Based On Information Technology As an Innovative Solution for Enhancing Community Welfare

Vieqi Rakhma Wulan, Agus Hermanto 
This incubation stage is for companies with a minimum annual turnover of \$ 9,375 USD or higher. These companies can become residents in incubation facilities or non-residents who preserve offices elsewhere. Companies are supported to connect to potential markets, access to finance, business advice, space and the internet for housing companies among others. The stages are:

a. Place to run a business

b. Strategic Market Network Support

c. Linkages with financing

d. Mentoring and coaching

e. Support to business development (legal, financial, consulting, and others)

f. Evaluation to exit

g. Access to the internet at high speed

h. Events of networking

i. Practice, displays and workshops

4. Graduates Companies/Alumni

This incubation stage is for companies that have passed and formed Alumni of business incubator. They partner with business incubator (DTBi) in conducting projects based on cost / income share. They are supported by services offered to others based on a case-by-case.

\section{Social Entrepreneurship (Sociopreneurship)}

Sociopreneurship and entrepreneurship have similarities that are to make profits, but different in the results. This is because the sociopreneurship experiencing alteration of meaning from what was originally considered a non-profit activity (through charitable activities) to a profiting activity. This is as said by Christie and Honig (2006); Weerawardena and Mort (2006) that the notions of social entrepreneurship have developed in several different domains, such as not-for-profit, for profit, the public sector, and a combination of the three, so that the integrated definition has not yet emerged. As also stated by Braun (2009) that the sociopreneur sees problems as an opportunity to form a new business model that is beneficial for the empowerment of surrounding communities. But the results to be achieved are not material benefits or customer satisfaction, but rather how the ideas proposed can have a good impact on the community (Susanto 2007).

The existence of Grameen Bank that provides micro-credit for the poor in Bangladesh is an example of a change in program orientation from entrepreneurship to sociopreneurship. This ultimately became the attraction of the business world to participate in sociopreneurship activities, because it turned out to generate financial benefits (Santosa 2007). The founder of Gramen Bank, Dr. Muhammad Yunus succeeded in developing a bank to serve the poor and make an innovation that was contrary to the general rule of the bank for those who were able and small risk. Access bottlenecks on funds faced by the poor have been solved by providing microcredit systems aimed at them in a group pattern. For his efforts to fight for the poor, Dr. Muhammad Yunus won the Nobel prize for peace in 2006.

It is indicates that sociopreneurship plays an important role in facing development challenges world economy. This is because sociopreneurship is something unique because it combines of social mission and business discipline.

Over the past few years, sociopreneurship has proven to be a very effective strategy for solving social problems and environmental problems, creating employment opportunities for marginalized groups, ensuring sustainable development, and reducing poverty. Sociopreneurship creates a fundamental shift to approaching development challenges, enabling people to start and take responsibility rather than (only) demanding change. Social, economic and environmental challenges in the world today are

Sociopreneurship Business Incubator Design Based On Information Technology As an Innovative Solution for Enhancing Community Welfare

Vieqi Rakhma Wulan, Agus Hermanto 
opportunities for the mindset of sociopreneurship to initiate change and produce impact (EyeOpenerWorks.org 2018).

\section{Business Incubator and Sociopreneurship}

In the process of incubation, several things are done to support the development of business (for sociopreneurship) ideas in addition to providing office space and other logistical conditions (Mendes 2013):

1. Suggestions for developing business cases;

2. Mentoring and coaching:

3. Building a team (sometimes ideas can come from one person or by team with imbalances in terms of gender and/or qualifications);

4. Interaction with other teams in the incubator, not only in matters development of social business ideas, but also on other matters;

5. In terms of developing business incubators in universities:

a. Interaction with university projects related to Social Economics;

b. Interaction with other socio-economic organizations and with relevant stakeholders outside the university;

6. Support in funding.

For incubators with social companies, Mendes (2013) continued, private investors who are willing to support them for a relatively long period of time are very difficult to found. In addition to public policies that are weak in supporting innovation, including social innovation sufficient funds will be difficult to found for this purpose.

Sahu (2018) in cases in India, highlighted that most social innovations are contextual and regional. Therefore it must be turned into a market-based solution with a business model that is acceptable to the community. So that system requirements are needed to facilitate the formation of ideas and innovations in society. This is what the social enterprise incubator must cover the required service portfolio including access to networks, mentoring, finance, and talent \& community involvement.

\section{The Information Technology Infrastructure Library (ITIL)}

The meaning of ITIL is the framework of a public in IT service management that describes best practices. A framework is provided for IT governance, and management and control of IT services. It focuses on measuring sustainability and improving the quality of IT services delivered, both from business and customer perspectives "(itSMF UK 2012).

\section{METHODOLOGY}

The method used in this study is Human Centered Design (HCD), with stages can be seen in table 1.

Table 1. Stage of Goals Human Centered Design (HCD)

\begin{tabular}{ccc}
\hline Hear & \multicolumn{1}{c}{ Create } & Delivery \\
\hline - Determine who will be & $\cdot$ Interpret data & . Identification of capabilities needed \\
\hline
\end{tabular}

Sociopreneurship Business Incubator Design Based On Information Technology As an Innovative Solution for Enhancing Community Welfare

Vieqi Rakhma Wulan, Agus Hermanto 
interviewed

- Get empathy

- Understanding the story

\section{Identify patterns \\ Defining opportunities \\ Creating a solution}

Creating a model for financial sustainability Develop an innovation pipeline Pilot plan and impact measurement

\begin{tabular}{|c|c|}
\hline $\begin{array}{l}\text { Outputs : } \\
\text { - Story/information } \\
\text { - Observation of field } \\
\text { conditions } \\
\text { - More understanding of } \\
\text { needs, obstacles and } \\
\text { constraints }\end{array}$ & $\begin{array}{l}\text { Outputs : } \\
\text { - Opportunities } \\
\text { - Solution } \\
\text { - Prototype }\end{array}$ \\
\hline
\end{tabular}

Of the three stages, the results of the research conducted by researchers were until the second stage, namely create because research is in accordance with the title stated, namely the design stage. While at the delivery stage, more in-depth continuous research is needed because it requires an assessment of feasibility, viability and several other stages for business incubators that are mature and ready for trial.

The sample in this study were 147 respondents (assuming as tenant candidates). In accordance with the HCD method, in the first stage-hear stage, the respondent was interviewed in depth to explore all information so that it can be known needs and problems that occur to build an assumption that can be used as a basis for designing a sociopreneurship business incubator. Then the results of the interview will be processed in stage 2, namely the create stage. Data is interpreted, identified and then defined with opportunities that can be created for a solution.

The results of the analysis HCD were then integrated with ITIL features designed for business incubators in this study. In addition, identification was also carried out in several business incubators and empowerment foundations to obtain information as a reference for the business incubator model that the researchers will design. The identification results are then analyzed to draw a conclusion so that a business incubator model design is obtained in accordance with the needs of prospective tenants.

The identification process was also carried out on several business incubators (business incubators $\mathrm{X}$ and $\mathrm{Y}$ ) also on community empowerment foundations namely $\mathrm{X}$ and $\mathrm{Y}$.

While for the ITIL stage can be seen in figure 1. The initial stage in planning information technology services is the stage requirement. At this stage, an assessment process and questionnaire distribution were carried out to the respondents so that the organization's business baseline and its existing conditions (as is condition) also the desired condition can be identified.

At the service strategy analysis stage, an alignment process is carried out between the results of the requirement, organizational policies, desired constraints, and service strategies.

After analyzing service strategy, a service design process is carried out by providing design solutions with architectures that are standard SDPs (Service Design Packages).

In the service transition phase, a transition service plan and testing solution with SKMS (Service Knowledge Management System) is carried out.

In the service operation phase, operational plans are carried out with service and repetitive operations, the service operations will affect the business/customer.

After carrying out various stages, the last stage is continuous improvement of service and good corrective action and planning. 


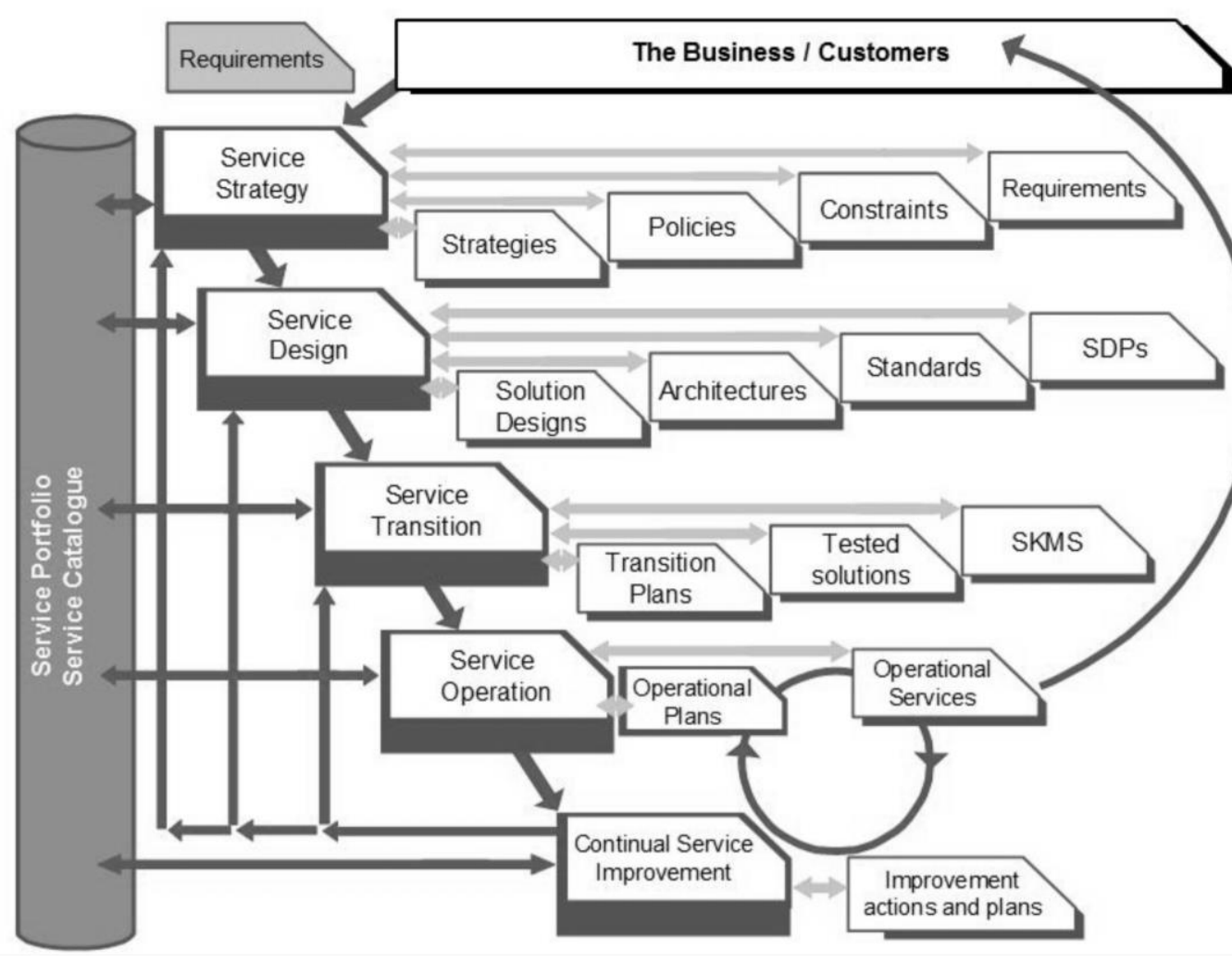

Figure 1. Life Cycle Information Technology Services Based on ITIL

Source: Smyth (2012)

\section{Characteristics of Respondents}

The characteristics of respondents can be seen in the table 2. In the table, from the total of 147 respondents, 58 respondents who were not willing to do training, in this case, who were not willing to develop themselves through a business incubator, there were several reasons such as: no costs, enough and comfortable with existing jobs, only able to do what is like being done now, old age, reasons health, no time and no interest.

While 89 respondents who stated their willingness to take part in the training consisted of varied characteristics, and dismissed the reasons for the unwilling groups. From the characteristics of age, it consists of all age groups ranging from the youngest ages, namely ages 20-39 years to the oldest age groups namely 80 years and above. This dismissed the notion that the elderly were unable to take part in the training. Both men and women are also ready to carry out training. The various types of work both scavengers, parking attendants, patchworkers tires, pedicab drivers, traders and others also expressed their willingness. This dismissed the notion that those who work in this type of work do not have abilities other than their jobs. Viewed from the time of work, 89 respondents who were willing also have varied lengths of work ranging from 0 to 30 years and above and gross income of 0 to 4 million and above. So here it can be seen that there is no reason for someone to be able to advance and develop because all that depends on the intention, desire and motivation to make it happen. 


\begin{tabular}{|c|c|c|c|c|}
\hline No & Characteristic & Type & Total & Percentage \\
\hline \multirow[t]{4}{*}{1} & \multirow[t]{4}{*}{ Age } & $20-39$ years & 27 people & $18,4 \%$ \\
\hline & & $40-59$ years & 79 people & $53,7 \%$ \\
\hline & & $60-79$ years & 34 people & $23,1 \%$ \\
\hline & & 80 years and above & 7 people & $4,8 \%$ \\
\hline \multirow[t]{2}{*}{2} & \multirow[t]{2}{*}{ Gender } & Male & 95 people & $64,63 \%$ \\
\hline & & Female & 52 people & $35,37 \%$ \\
\hline \multirow[t]{6}{*}{3} & \multirow[t]{6}{*}{ Type of Work } & Scavenger & 6 people & $4,1 \%$ \\
\hline & & Parking Officers & 7 people & $4,8 \%$ \\
\hline & & Tire Repairs & 7 people & $4,8 \%$ \\
\hline & & Pedicab Driver & 14 people & $9,5 \%$ \\
\hline & & Trader & 85 people & $57,8 \%$ \\
\hline & & Many More & 28 people & $19 \%$ \\
\hline \multirow[t]{5}{*}{4} & \multirow[t]{5}{*}{ Length of Work } & $0-4$ years & 42 people & $28,57 \%$ \\
\hline & & $5-9$ years & 30 people & $20,41 \%$ \\
\hline & & $10-19$ years & 42 people & $28,57 \%$ \\
\hline & & $20-29$ years & 21 people & $14,29 \%$ \\
\hline & & 30 years and above & 12 people & $8,16 \%$ \\
\hline \multirow[t]{5}{*}{5} & \multirow[t]{5}{*}{ Money Earned } & $0-1$ million & 31 people & $21,1 \%$ \\
\hline & & $1,01-2$ million & 53 people & $36,1 \%$ \\
\hline & & $2,01-3$ million & 45 people & $30,6 \%$ \\
\hline & & $3,01-4$ million & 9 people & $6,1 \%$ \\
\hline & & 4,01 million and above & 9 people & $6,1 \%$ \\
\hline \multirow[t]{2}{*}{6} & \multirow{2}{*}{$\begin{array}{l}\text { Motivation to } \\
\text { participate } \\
\text { training }\end{array}$} & Disposed & 89 people & $60,54 \%$ \\
\hline & & Not disposed & 58 people & $39,46 \%$ \\
\hline
\end{tabular}

\section{Characteristics of Business Incubators and Empowerment Foundations}

\section{Business Incubator $X$}

This business incubator has programs and activities including: Mentoring, Coaching and Evaluation, and Mentoring, as shown in the following figure 2.

Sociopreneurship Business Incubator Design Based On Information Technology As an Innovative Solution for Enhancing Community Welfare 


\begin{tabular}{|c|c|c|}
\hline MENTORING & COACHING \& & ASSISTANCE \\
\hline $\begin{array}{l}\text { Reviewing the } \\
\text { preparation of the Business } \\
\text { Plan, Action Plan, } \\
\text { Corporate Management, } \\
\text { Finance, Product Legality, } \\
\text { Product Development, } \\
\text { Marketing and other things } \\
\text { needed by tenants to } \\
\text { develop their business }\end{array}$ & $\begin{array}{l}\text { The purpose of this } \\
\text { activity is to determine the } \\
\text { development of tenant } \\
\text { business activities. } \\
\text { Evaluation } \\
\text { conducted periodically: } \\
\text { 1) Evaluation of Semester } \\
\text { 2) Evaluation of Annual }\end{array}$ & $\begin{array}{l}\text { Assistance and } \\
\text { direction to tenants, in } \\
\text { managing } \\
\text { Legality and Business } \\
\text { Certification }\end{array}$ \\
\hline
\end{tabular}

Figure 2. Programs and Activities of Business Incubator $X$

Apart from the three stages described in the figure 2, business incubator $\mathrm{X}$ is also still providing assistance in the form of training, FGD and business matching, seminars to exhibitions. Training is conducted to develop insights and improve the ability of tenants to execute business. The FGD and Business Matching aims to bring together prospective investors or prospective buyers with tenants from Industrial Incubator X. Seminar activities are meetup activities or meet with resource persons who are competent in the business world, and hold discussions with the aim of increasing knowledge and experience of their entrepreneurship program (technopreneurship) and can be an inspiration for tenants from Industrial Incubator X. The exhibition activity aims to promote tenant goods to potential investors and buyers.

\section{Business Incubator $Y$}

This operational activities opening starting at 8:00 - 17:00 Monday to Friday and 09:00 - 15:00 for Saturday. Open recruitment system that is in the form of tenant job information is done to get tenant participants.

This business incubator is divided into 3 stages of activity namely pre-incubation, incubation and post-incubation. For the pre-incubation stage consists of Bootcamp, Matriculation of Material, and Workshop. For the initial incubation included technical and management training, business legality assistance, business plan creation, production trials, and IPR registration assistance. While the guiding mechanism at this incubation stage consists of 4 activities, namely: first, Coaching Business as a mechanism to develop tenant skills and knowledge, so that performance improves, and leads to achieving goals. In this mechanism, using Coach to help direct, ask questions, explain other perspectives, help tenants solve problems faced by businesses, find solutions and develop solutions. strategic plan. Second, Mentoring is a mechanism for sharing experiences and knowledge from someone who has experience in a particular field. The mechanism of the main role in the Mentor is usually someone or businessman who is already experienced in his field so that he can guide, provide tips and advice and solve business problems faced by tenants. Third, Consulting Business is a mekanieme to help an expert (consultant) to solve problems faced by tenants, and help tenants formulate business strategies, operations strategies and future development. Fourth, Training/Workshop is a mechanism for transferring skills / abilities to trainees. In the incubation process there will be some transfer given to special tenants in important practice areas such as financial management, financial recording and reporting, building quality management systems, leaderships etc. And the last stage, namely post-incubation, all tenants are expected to:

1. Has the ability to carry out business development characterized by product development, market development and business unit development, 
2. Have mental maturity, motivation, skill and mastery in business processes. In some ways it is termed the maturity of managing a business,

3. Successfully building networks, partnerships and even synergy

4. Have the ability to enter the market, adapt and the ability to compete on the basis of having a competitive advantage.

\section{Empowerment Foundation $X$}

This foundation has an empowerment program in the form of providing working capital, assistance and coaching to coached participants so that they can execute their own business. Coached participants are participants from the lower middle class so that they are able to improve their standard of living.

In conducting the coaching, beforehand, the empowerment foundation $\mathrm{X}$ conducts an assessment to the participants by looking at the economic conditions, abilities and willingness of the participants so that they can be determined to be feasible or not they become members.

\section{Empowerment Foundation $Y$}

Empowerment activities combined with community development in this foundation are part of one of the pillars of the program, the social humanitarian which aims to improve the lives of underprivileged people. These activities include skills training, micro-enterprises and the development of home industries, improvement of community sanitation and provision of clean water facilities, urban agriculture/livestock, cultural preservation and disaster response. For its own skills training activities, empowerment foundation $\mathrm{Y}$ held several work skills training such as sewing, embroidery, salon/haircut, bridal makeup and entrepreneurship training in collaboration with one of the existing universities.

\section{RESULTS AND DISCUSSION}

In principle, the model of the design of the sociopreneurship business incubator is refers to the standard business incubator model in general. But the differences found in business incubators designed by researchers is the existence of a sociopreneurship program. In addition to being provided with insight and good knowledge about the business to be conducted and the technology used, tenants are also provided with spiritual insights and communication skill to become mentors so they can fostering other communities to be skilled and entrepreneurial and be able to be sustainable to other communities. Therefore, in addition to business assistance, mentoring of the movement to become a mentor will also be conducted.

Besides tenants are also provided with insights into simple technology (considering that respondents are the lower class of workers), which is like the practice of habituation with online media for business needs. The sociopreneurship business incubator is also integrated with the technology system to facilitate access and management by using ITIL (Information Technology Infrastructure Library).

\section{Field of Business Incubator}

Based on the results of interviews that have been conducted regarding the desires, needs and expertise of the respondents, the business incubator that will be designed is focused on the following areas:

1. Agriculture

2. Trade

Sociopreneurship Business Incubator Design Based On Information Technology As an Innovative Solution for Enhancing Community Welfare

Vieqi Rakhma Wulan, Agus Hermanto 
3. Repair and technicians

4. Food and restaurant/depots

5. Crafts

6. Sewing, embroidery, and others

7. Salon and spa

\section{Preparation Stage/Inf rastructure Services}

This service is in the form of facilities provided at the incubator to support the business. This service is in the form of:

1. Office room

2. Meeting room

3. Business space of tenants

4. Telecommunication facilities including the internet

5. Office equipment

\section{The Implementation Phase of the Business Incubator}

The implementation phase of the incubator is divided into 2, namely co worker space and event space. Co worker space is a space that used to conduct the core of the activities that will be carried out in the business incubator. While event space is a space for events that can be used to help tenants so that products can be known by the community and supporting facilities so that tenants are more advanced, developing and can expand their business. Co worker space and event space illustrated in figure 3 and figure 4.

\section{Graduation}

At this stage, tenants are ready to be released independently both to manage their own business and to mentor the wider community. But contact with the incubator and with mentors is still done so that the target can be implemented and achieved effectively.

\section{The Design of Information Technology Services Management}

The design was made using ITIL v3, in the service strategy phase, so that the relationship between business incubators, the internet and business performance can be seen, in figure 5 .

As seen in figure 5, the nature of business results determines the customer assets needed by the business unit. Furthermore, business incubators can use these service assets to provide services that meet the needs of business units. To achieve results, business units require a minimum level of service. The business unit can then determine whether service performance is appropriate for activating the assets of its customers.

Sociopreneurship Business Incubator Design Based On Information Technology As an Innovative Solution for Enhancing Community Welfare

Vieqi Rakhma Wulan, Agus Hermanto 


\section{:: IJEBD :}

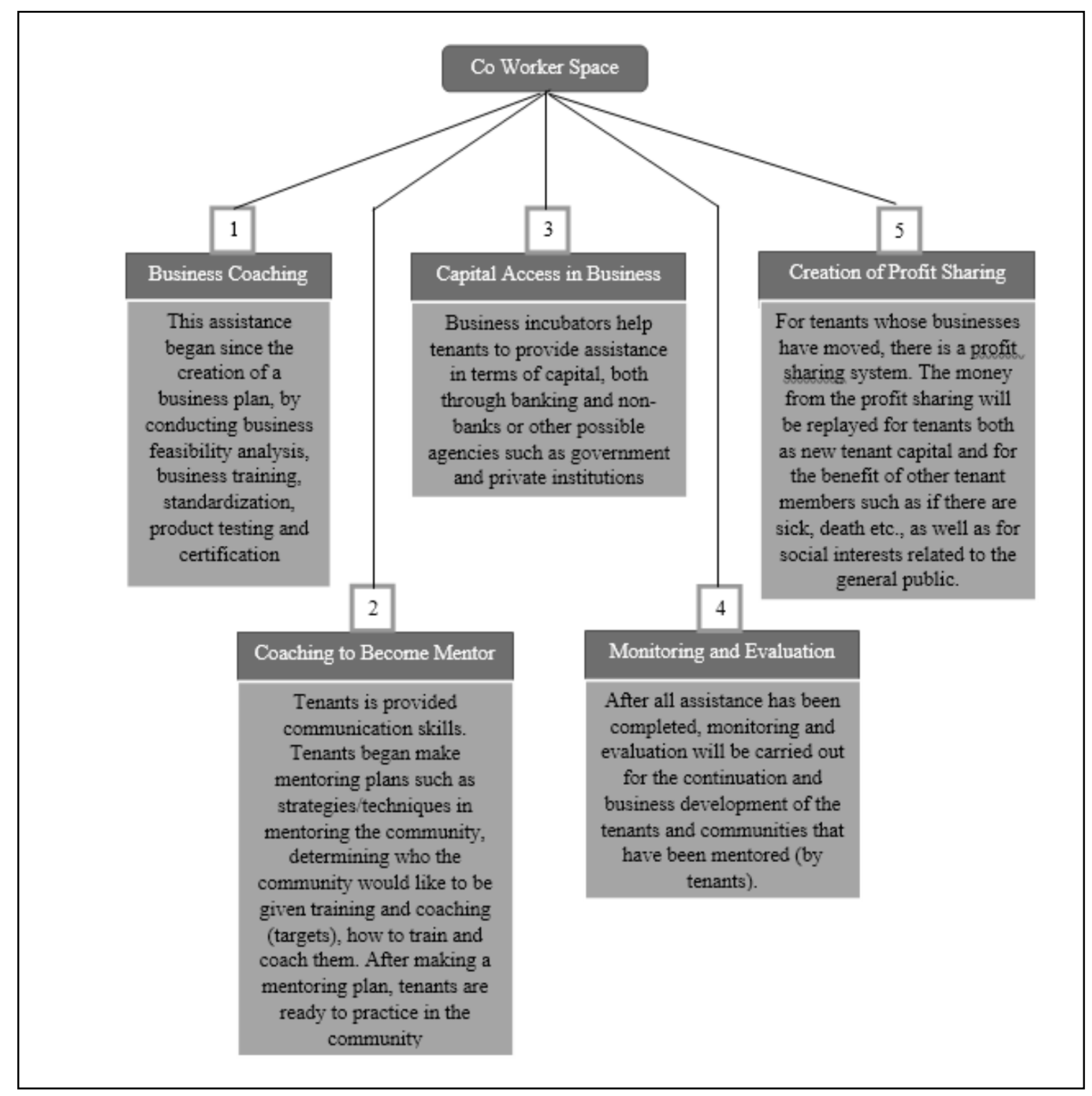

Figure 3. The Implementation Phase of the Business Incubator (Co Worker Space) 


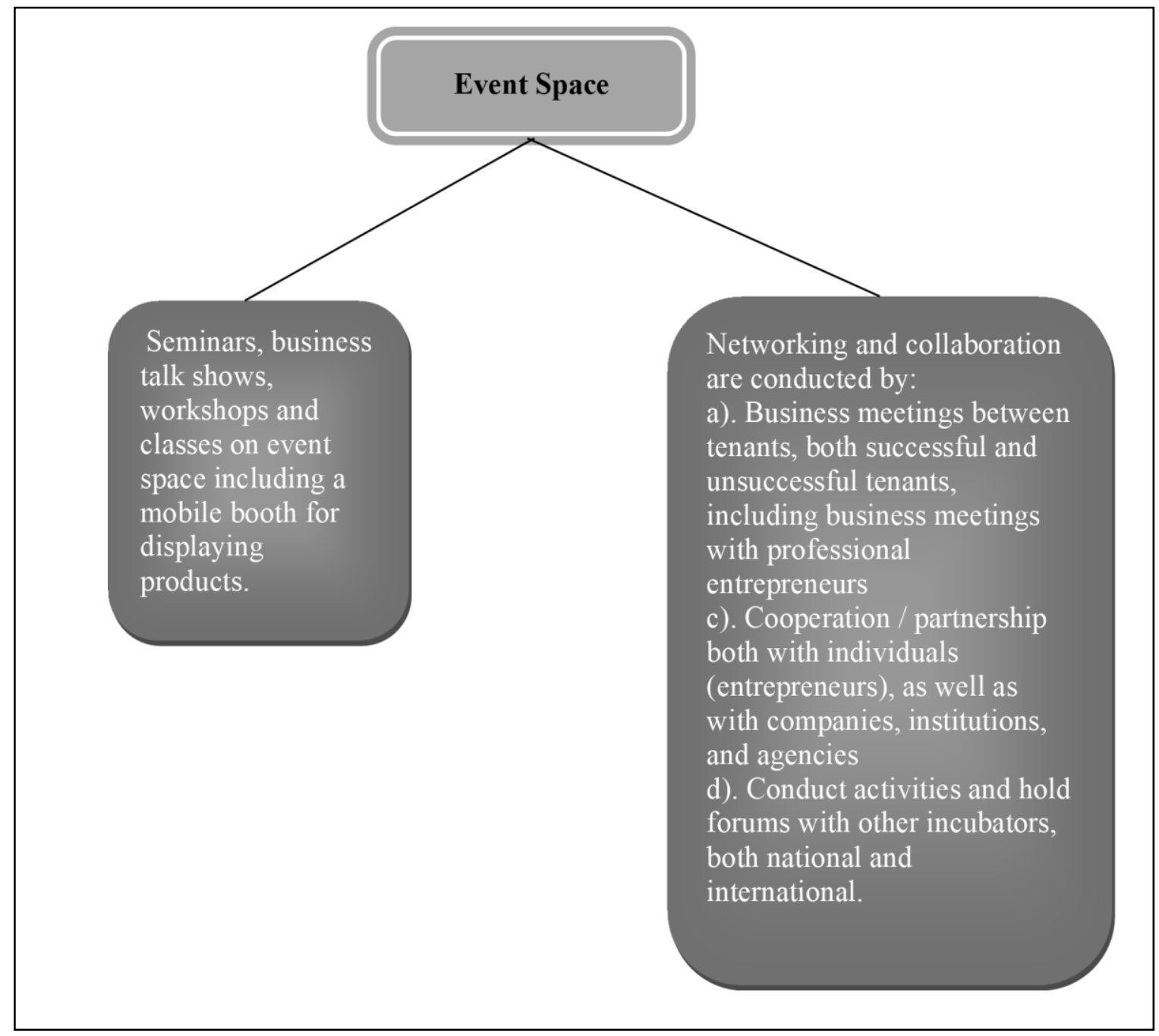

Figure 4. The Implementation Phase of the Business Incubator (Event Space)

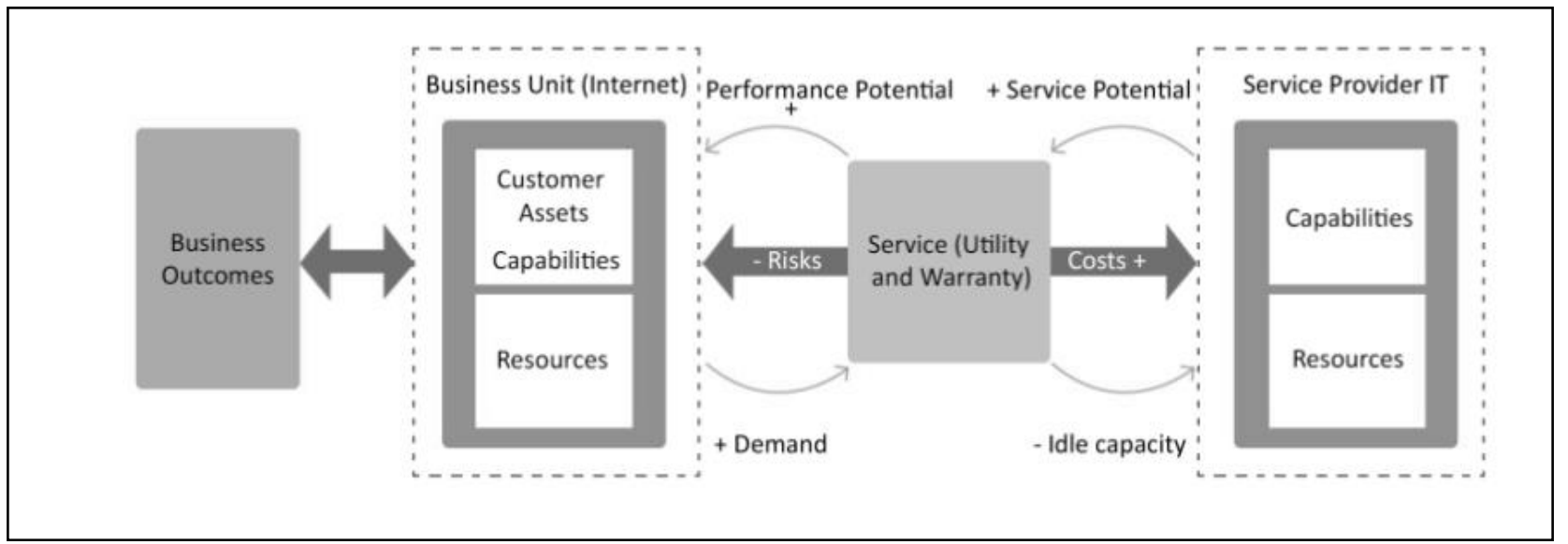

igure 5. Relationship Diagram Between Entities in MLTI Design

Sociopreneurship Business Incubator Design Based On Information Technology As an Innovative Solution for Enhancing Community Welfare

Vieqi Rakhma Wulan, Agus Hermanto 
IT services are focused on the success of providing services that meet customer needs and providing added value from the services provided, then to be able to understand the concept of IT services can be seen in Figure 6. In this diagram you can get an overview of aspects or components used to compile and develop information technology services ITIL based.

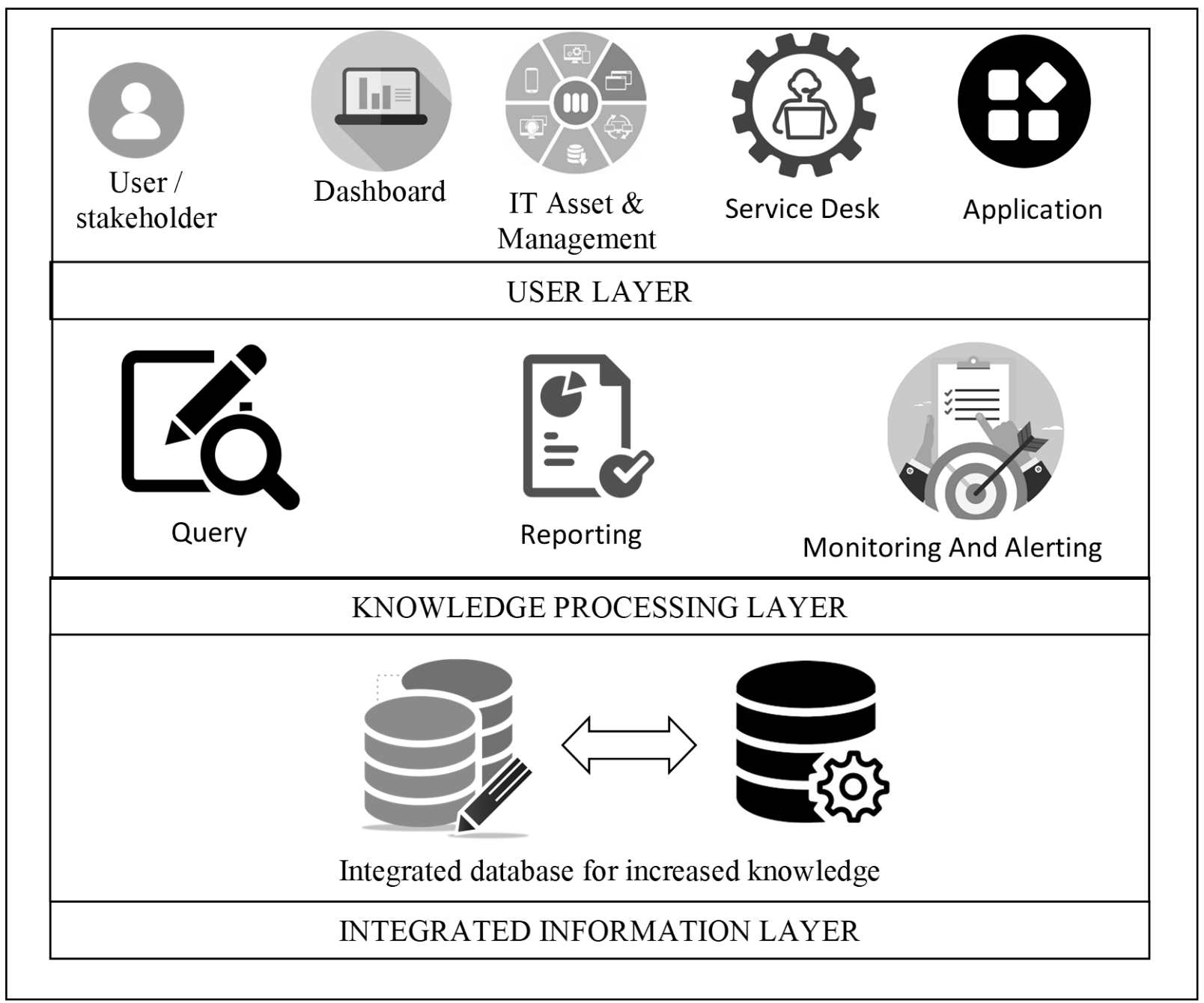

Figure 6. The Design of IT Service Package Development for Business Incubator

\section{CONCLUSION}

In business incubators designed by researchers it is not much different from business incubators in general. Such as business incubator program activities, similar to what was stated by Almubaraki and Busler (2011) and several examples of business incubators also empowerment foundations that have been observed. But because the business incubator is designed to focus on sociopreneurship, the existing activities must cover this. Such as activities to mentor the surrounding community and assist them. Those who have been mentored also continue to mentor people and other communities and keep continue. Therefore in this case communication skill is emphasized and the other most important thing obtained during the observation that the success of tenants and business incubators is the provision of spiritual insight that is always applied daily.

Sociopreneurship Business Incubator Design Based On Information Technology As an Innovative Solution for Enhancing Community Welfare

Vieqi Rakhma Wulan, Agus Hermanto 
Based on the interviews that have been conducted, the results state that the training program that is realized in business incubators is in demand by anyone, both young and old, both women and men, from all professions and from whatever their income. But the most important thing is that those who want training are those who have strong motivation to advance and develop. There is no reason for someone to be able to progress and develop because it all depends on the intention, desire and motivation to make it happen.

\section{ACKNOWLEDGMENTS}

We express our deepest gratitude to the Directorate of Research and Community Service, the Directorate General of Higher Education who has provided research grants so that this research can be carried out.

\section{REFERENCES}

Almubaraki, Hanadi and Busler, Michael. (2011). Critical Activity of Successful Business Incubation. International Journal, IJES, 1 (3), 455-464, September 2011.

Anoviar, Alia Noor, (2013). Gejolak Revitalisasi Gerakan Mahasiswa di Indonesia dalam Kerangka Social Entrepreneurship. Makalah. Dari laman web Kajian tentang Bisnis Sosial (Social Entrepreneurship).

Braun, Karen, (2009). Social Entrepreneurship: Perspectives on an Academic Discipline. Theory in Action, Vol. 2, No. 2, April 2009. page. 34.

Christie M, Honig B, (2006). Social entrepreneurship: new research findings. Journal of World Business 41(1):1-5.

DTBi. (2015). Stages of Incubation. Apply for Incubation. Available from: http://teknohama.or.tz/stagesof-incubation/

EyeOpenerWorks.org, (2018). Social Business Incubation. Available from: http:// eyeopenerworks.org/wp-content/ uploads/2017/07/Social-Business-Incubation-product-sheet.pdf

IDEO, $2^{\text {nd }}$ edition, [online]. Ideo HCD Toolkit. Available from: http://www.ideo.com/images/ uploads/hcd_toolkit/IDEO_HCD_ToolKit.pdf

Idris, Indra, (2012). Kementerian Koperasi dan UKM Deputi bidang pengkajian sumberdaya UKMK: Panduan model pengembangan Inkubator bisnis.

InfoDev. Org. (2010). 01 Business Incubation Definitions and Principles. Washington DC: World Bank Group. Available from: www.infodev.org/businessincubation

itSMF UK, (2012). An Introductory Overview of ITIL 2011. London : TSO.

Mendes, Americo M.S. Carvalho. (2013). Why are Incubators Important for Social Innovation?. Available from: $h$ ttps://www.researchgate.net/publication/303692804_Why_are_incubators_important_for social innovation

Santosa, Setyanto P., (2007). Peran Social Entrepreneurship Dalam Pembangunan. Dialog “Membangun Sinergisitas Bangsa Menuju Indonesia yang Inovatif, Inventif dan Kompetitif” Himpunan IESP : Universitas Brawijaya, Malang, Indonesia, 14 Mei 2007

Sahu, Dipan Kumar. (2018). Social Enterprise Incubator - An Emerging Model of Social Innovation System Development in India. Available https://www.academia.edu/10223930/Social_Enterprise Incubator_An_Emerging_Model of Social_Innovation_System_Development_in_India

Smyth, Tom. (2012). ITIL Service Portfolio Management. Writer's site: https://tomjsmyth.wordpress.com/2012/08/22/what-is-itil-service-portfolio-management/

Susanto. A.B, (2007). Corporate Social Responsibility. Jakarta : The Jakarta Consulting Group, page. 54 UnLtd-Indonesia, (2108). About UnLtd Indonesia. Available from: http://unltd-indonesia.org/

Weerawardena J, Mort GS. (2006). Investigating social entrepreneurship: a multidimensional model. Journal of World Business 41(1): 21-35. 